\title{
A natureza humana do comportamento individual nos primórdios do pensamento econômico: uma comparação entre Hume, Smith e Bentham *
}

\author{
Glaucia Campregher ** \\ Lucas Schönhofen Longoni ${ }^{* * *}$
}

A Natureza Humana é a única ciência do homem; entretanto, até aqui tem sido a mais negligenciada.

David Hume

\begin{abstract}
Resumo
Busca-se compreender como a relação entre indivíduo e contexto social-histórico fazia-se presente nas teorias e especulações filosóficas de Hume, Smith e Bentham - enfocando o papel concedido à natureza individual, suas supostas tendências ou predisposições inatas, sejam elas racionais ou passionais. Principalmente em Hume e Smith, observa-se que a capacidade natural de nos importarmos com o outro, sympathy, não diz muito em si mesma, mas ganha concretude com o hábito. Já em Bentham, a sympathy, que faz o indivíduo sair de si e se reconhecer no outro, dará lugar ao indivíduo isolado, o que impossibilita a superação de uma "natureza natural" por uma natureza histórico-social do homem.
\end{abstract}

Palavras-chave: Natureza humana; Simpatia; Utilitarismo; Hume, David, 1711-1776; Smith, Adam, 1723-1790; Bentham, Jeremy, 1748-1832.

\section{Abstract \\ The human nature of individual behavior in the early days of economic thought: a comparison of Hume, Smith and Bentham}

The objective of this study is to understand how the relationship between individual and socialhistorical context was present in the theories and philosophical speculations of Hume, Smith and Bentham - focusing on the role of the individual nature, and its supposed innate tendencies or predispositions, whether rational or passional. Hume and Smith, in particular, observe that the natural capacity to care for the other, sympathy, does not say much in itself, but becomes more concrete as the act becomes a habit. Although in Bentham, sympathy, which enables the individual to see himself in the other, will lead to the isolated individual, what makes it impossible to overcome a "natural nature" by the historical and social nature of man.

Keywords: Human nature; Sympathy; Utilitarism; Hume; Smith.

JEL B12, B40.

${ }^{*}$ Artigo recebido em 27 de fevereiro de 2015 e aprovado em 18 de janeiro de 2017.

** Professora no Departamento de Economia e Relações Internacionais da Universidade Federal do Rio Grande do Sul (UFRGS), Porto Alegre, RS, Brasil. E-mail: glaucia@ campregher.com.

${ }^{* * *}$ Bacharel em Economia e mestrando em Filosofia pela Universidade Federal do Rio Grande do Sul (UFRGS), Porto Alegre, RS, Brasil. E-mail: schonhofen.longoni@ufrgs.br. 


\section{Introdução}

A aurora do pensamento racional coincide com a perda da unidade (e até identidade), um tanto mística ou mágica nos povos primitivos, entre parte e todo, os homens (e seus grupos) e o universo inteiro (céus, terras e seus habitantes) (Safatle, 2006, p. 309). Uma vez perdido esse elo mágico com o todo, contudo, a história da filosofia e da ciência não deixa de ser a história da produção de outros conjuntos de partes e todos, e de discursos que os conectam. Assim, se criar objetos de reflexão é subtraí-los a um todo natural, é também instalá-los numa relação outra entre todo e partes componentes. Pode-se dizer também que objetos científicos novos nascem quando o que era parte, numa construção anterior, ganha tanta atenção que passa a se constituir num novo todo ${ }^{1}$. Assim, nem bem nasce um objeto para o pensamento científico, definir o que é a parte e o que é o todo deste - e como se relacionam, e se transformam - é seu primeiro grande desafio. Muito provavelmente, os métodos de investigação se distingam uns dos outros a partir desse primeiro procedimento, de secção e reunião. Perguntamo-nos, no caso da economia, o que é a parte e o que é o todo? Podemos dizer que a parte é a unidade de ação/decisão, as pessoas - mais ou menos individualizadas ${ }^{2}$-, ou, simplesmente, o indivíduo; e o todo é a sociedade eventualmente a tribo, clã, cidade, império, ou nação geográfica, mas também historicamente (e até politicamente) delimitados? E como se dá a relação entre partes e todo nesse caso? Ou, até que ponto as ações dos indivíduos "fazem" o todo (suas instituições, valores, leis), e até que ponto é o todo que "faz" os indivíduos? Além disso, se ocorre inventarmos uma ciência nova para a parte que "cresceu", como é a psicologia para o estudo do indivíduo, como as novas descobertas desta vão ser compreendidas pela ciência já estabelecida? Não corremos o risco de que o indivíduo se torne cada vez mais "soberano" e que, por tabela, sobrevalorize as determinações próprias do todo do qual é parte? Ou, ao contrário, as contribuições de uma ciência dedicada ao estudo do indivíduo poderiam cobrir lacunas dentro das teorias que, centrando-se no todo, esvaziavam o seu papel?

É de amplo conhecimento que a bifurcação do pensamento econômico a partir de Ricardo nos legou uma corrente (o marxismo) mais focada no todo, seja ele a sociedade e suas classes em conflito, seja o capital e seus interesses, em grande medida também conflituosos; e uma outra (o neoclassicismo) mais focada no indivíduo e nas articulações harmônicas entre eles. Entretanto, podemos dizer que

(1) Obviamente essa não é a única circunstância requerida, nem queremos disputar aqui quão central seria. Para maiores aprofundamentos acerca do surgimento de novas ciências, objetos, teorias e paradigmas científicos, ver Kuhn (1989); Popper (1993) e Lakatos e Musgrave (1979).

(2) Assim posto, descremos de um "individualismo metodológico" que se instaure a priori. Acreditamos que, quanto mais atrás na história, menos os indivíduos aparecem enquanto tais, unidades de decisão e ação, e mais as pessoas se vêm presas às suas comunidades e mesmo ao ambiente natural, como nos mostram os antropólogos. Apenas para citar um destes cujos trabalhos são bastante conhecidos entre os economistas, ver Polanyi, Arensberg e Pearson (1957). 
nem marxistas, nem neoclássicos se dedicaram a pensar mais cuidadosamente o indivíduo como seus predecessores, Hume, Smith e Bentham, para ficarmos com os mais importantes. Marx porque parte da noção de que não existe nada fixo no indivíduo, dada a mutabilidade do todo do qual é parte - ou seja, não há qualquer essência, qualquer natureza humana que nos caracterize a priori fora da sociedade, ou, como dizia ele, fora do "conjunto das relações sociais"3. E os neoclássicos porque, ao contrário, não existe nada móvel; ou ainda, aquelas motivações que são mutáveis (gostos, tradições, valores) e que podem ser mesmo úteis para entender as ações do indivíduo em todas as áreas ${ }^{4}$, na área que interessa à economia, são dispensáveis. Ou seja, para entender o comportamento econômico bastaria supor a escolha racional como fazendo parte da natureza humana.

Essa discussão, da natureza humana, não ficou, contudo, abandonada desde os primórdios da economia. De fato, deu origem a toda uma leva de pesquisas dedicadas ao papel do indivíduo nas várias escolas do pensamento econômico. Nossa impressão, não obstante, é que a maioria dos estudos tem focado principalmente o individualismo como ponto de partida metodológico (sobre o que abundam trabalhos em todas as tradições do neoclassicismo ao marxismo) ${ }^{5}$, esquecendo assim seu aspecto ontológico. Podemos dizer que durante anos, entre marxistas, bastou a menção à sexta tese sobre Feuerbach para negar qualquer "natureza" ao homem; e mesmo quando veio à luz a ousada obra de Lukács, sua Ontologia do ser social, esta não teria seguidores na economia que pudessem explicitar melhor como a história se faz uma "segunda natureza" (como dizia Marx) a dirigir as ações dos indivíduos. De outro lado, neoclássicos continuavam a afirmar o homem econômico racional, hedonista e calculador de utilidades como sendo sua natureza, sem mais investigações. Mas o interessante é que, nos anos recentes, os progressos da biologia, psicologia, antropologia e neurociências (ainda mais atuais) trouxeram de novo à baila tal questão, revelando um novo ramo na economia dedicado à observação empírica do comportamento dos indivíduos (denominado psicologia econômica ou economia psicológica, ou neuroeconomia, conforme se definam seus protagonistas), sobre o qual nos debruçamos em outro lugar. No entanto, antes de tudo seria necessário, segundo um programa cronológico, checar os primeiros economistas (de fato, os fundadores de nossa ciência), que tinham como fundamento filosófico

(3) Isso porque, como Marx explica na sexta tese contra Feuerbach, “[...] a essência humana não é algo abstrato inerente a cada indivíduo. É, em sua realidade, o conjunto das relações sociais” (Marx, 1996, p. 180).

(4) Nesse sentido, Mill (indo no sentido oposto de Hume e Smith, como veremos aqui) irá separar o que é da natureza e o que é da sociedade no comportamento humano, e dirá que não interessa à economia política o todo do comportamento humano, mas apenas aquela parte que diz respeito a "[...] um ser que deseja possuir riqueza e que é capaz de julgar a eficácia comparativa dos meios para obter aquele fim” (Mill, 1974, p. 300). No mesmo sentido, ver Pareto (1996).

(5) Ver Levine, Sober e Wright (1987) e Prado (1989). 
justamente a observação empírica como base de suas concepções sobre o comportamento individual.

Logo, o que segue resulta de nossas reflexões acerca de como consideraram os indivíduos aqueles que os olharam mais de perto via especulação filosófica - os citados Hume, Smith e Bentham - os dois primeiros tentando se entregar à observação mais que à dedução. Interessa-nos, particularmente, saber como, a partir dessa preocupação, esses filósofos/economistas concebem o que é da natureza e o que é da sociedade no que concede ao comportamento individual, uma vez que, a despeito das dificuldades, esta última se dava mais às suas observações. Principalmente nos interessa checar como observam o ambiente (as circunstâncias, como diria Hume) ou todo o complexo de relações (materiais e subjetivas, diríamos nós), influindo na natureza e, mesmo, alterando-a, transformando-a em algo menos fixo e, até mesmo, menos natural.

Dito isso, este artigo conta, além desta introdução, com uma seção para cada um dos autores - Hume, Smith e Bentham. As comparações entre os autores acontecem em meio à apresentação de suas teorias. Por fim, apresentamos a conclusão a fim de sintetizar o que consideramos principal para que seja possível a todos os leitores construir uma compreensão mais rica e mais determinada acerca da relação parte/todo e indivíduo/sociedade.

\section{A simpatia pela observação levando Hume à observação da simpatia}

David Hume (1711-1776) é considerado um dos precursores da ciência econômica, tendo influenciado particularmente a Adam Smith (1723-1790). Ambas as teorias acerca da natureza do comportamento dos indivíduos pretendiam ser uma nova base para a defesa da moralidade, despindo-a de pressupostos religiosos ${ }^{6}$ ou, como diria Hume, dogmáticos e metafísicos - crítica aos a prioris da razão, absolutamente não vividos pelos homens. Segundo Hume, sua tarefa era justamente "tentar introduzir o método experimental de raciocínio nos assuntos morais", assuntos estes que estariam fundidos com o pensamento econômico, assim como com outras ciências em seus primeiros passos. Sua visão sobre nossa ciência é que esta seria empírica por excelência, porque teria por objeto questões de "fato e existência”, as quais não poderiam ser sustentadas exclusivamente pela razão ${ }^{7}$.

(6) É importante ressaltar que não adentraremos as discussões sobre o tipo de influência que o discurso religioso adquiriu na visão teórica de Smith. Para tal, ver Cerqueira (2006).

(7) Para os não entendidos, Hume dividiu as possibilidades do entendimento em dois tipos de operação: a) raciocínio demonstrativo, concernente a relação de ideias e b) raciocínio moral ou provável, referente às questões de fato e de existência. O primeiro tipo comporta a Matemática e as demais relações formais de ideias abstratas, e o segundo comporta disciplinas empíricas, como a Economia, que depende do estudo histórico - campo das experimentações de onde o conhecimento provém (Kuntz, 1983). 
Contudo, em Hume, e também em Smith, como veremos, há no que a experiência (hábitos, circunstâncias) nos informa, algo que se mantém - e é mais claramente identificado ao que é "da natureza" -, e algo que muda, sem sequer sabermos por que (porque não acessamos as causas últimas de coisa alguma). Não é essa mutabilidade, entretanto, que diz que é impossível conhecer a natureza das coisas, mas as insuficiências da razão. Não se trata, pois, de abstrair o movimento para que tenhamos límpida a essência (o que faz o falso empirismo do neoclassicismo mainstream). Essas circunstâncias não são acidentes a serem descartados; ao contrário, são elas, ou por meio delas ${ }^{8}$ que se evidencia o que é da essência, mesmo que assim esta se veja reduzida a poucos princípios. Vejamos de perto como isso se passa em Hume, mantém-se e até se radicaliza em Smith, até começar a se perder em Bentham.

Em Hume, a natureza humana aparece, via de regra, como um substrato comum (princípios do entendimento), um pano de fundo possível sobre o qual o conjunto das experiências pode se desenvolver, o que muitos comentadores irão chamar de uma "[...] realidade última e definitiva [...]" (Cerqueira, 2006, p. 7), mas que escapa ao entendimento prático no terreno da moral. Essa base seria, no entanto, original, estável e imutável, correspondendo ao que os homens seriam na sua "essência" fora da história, ou, ainda, o que todos teríamos em comum, a despeito das nossas diferenças de temperamento e caráter. Nas palavras do autor:

Existe um curso geral da natureza nas ações humanas, assim como nas operações do sol e do clima. Existem também caracteres peculiares a diferentes nações e a diferentes pessoas, e outros que são comuns a toda a humanidade. O conhecimento desses caracteres se funda na observação da uniformidade das ações deles decorrentes; e essa uniformidade constitui a própria essência da necessidade (Hume, 2009, p. 439).

Mas essa base é muito limitada dada a importância que Hume dá à diversidade das circunstâncias e ao seu poder de determinar mesmo a "constituição interna" de um homem, como pode ser visto na seguinte citação:

A pele, os poros, os músculos e os nervos de um trabalhador são diferentes daqueles de um homem de qualidade; assim também seus sentimentos, ações e maneiras. As diferentes condições sociais influenciam toda a constituição, externa e interna; e essas diferentes condições decorrem necessária, porque uniformemente, dos princípios necessários e uniformes da natureza humana (Hume, 2009, p. 438, grifo nosso).

Mas se é interessante ver como Hume não faz tabula rasa do todo social e mutante, o que resta uniforme, por trás desse emaranhado, na regência prática da

(8) Mesmo que não sejam tratadas rigorosamente, ou seja, historicamente, como faz ao seu modo um outro “tipo de empirismo", que é ao nosso ver o materialismo histórico. 
ação dos indivíduos, não fica tão evidente. Em parte isso se passa por causa da própria proximidade da moral com a natureza. Como salienta Kiraly, não há nada de natural na moral justo porque "[...] não há nada de natural na natureza [...]” (Kiraly, 2010a, p. 121, grifo do autor). Ou, tomando todo o raciocínio de Kiraly:

A moral é inafastável da natureza humana, pois não nos é dada a experiência de homens que não se preocupem, em alguma sorte com suas ações. Contudo, a moral não é um construto lógico obediente aos princípios da razão. Se na primeira acepção a moral é natural, na segunda, não há nada de natural nela (Kiraly, 2010a, p. 121).

Ou seja, se é da moral o julgamento do que é bem e mal, justo e injusto, e se não há nada na própria razão que ofereça uma base transcendente a esses julgamentos, há que procurá-los na natureza, mas a natureza também não os dá. A natureza dá a capacidade de julgar tão somente. Ou, como diz Hume, “[...] a natureza, por uma necessidade absoluta e incontrolável, determinou-nos a julgar, assim como a respirar e a sentir" (Hume, 2009, p. 216), mas os critérios do julgamento provém do hábito. Não há nada de substantivo no julgar, e sua naturalidade repousa nos sentidos sem maiores considerações sobre se o que os provoca, “[...] os objetos não possuem absolutamente nenhum valor em si mesmos, seu valor deriva exclusivamente da paixão [...]" (Hume, 1985 apud Conte, 2006). No máximo, consideramos, ou devemos considerar segundo os nossos sentidos. Estes nos dão a base para aquela avaliação por aproximação, uma vez que as paixões derivam de uma busca direta do bem e aversão ao mal. Assim,

Aprovar um caráter é sentir um deleite com o seu aparecimento, e desaproválo é ser sensível a um desgosto. Portanto a dor e o prazer, sendo de certo modo a fonte primeira da censura ou elogio, devem ser também as causas de todos os seus efeitos, sendo portanto também as causas do orgulho e da humildade, inevitáveis acompanhantes dessa distinção (Hume, 2005, p. 18).

Conclui-se que a natureza não está amordaçada pela moral, nem amordaça a esta. Ambas as ocorrências estão conectadas por redes parciais de simpatias (sympathy) que vão sendo estruturadas, reforçadas e expandidas. As ações humanas resultariam, assim, de uma cadeia de relações entre informações mediadas do exterior, com o que possibilita o sentir, de modo que, em última instância, são sempre essas informações adquiridas pelas experiências que dão base para o agir. As simples funções, ou princípios da natureza, não possuem esse poder. Esses somente permitem o acendimento das paixões pelas impressões externas. Portanto, as paixões é que constituem o princípio ativo do sujeito ${ }^{9}$ e atuam como intermediário entre a

(9) O juízo, ou a consideração racional, seria o princípio inativo, “[...] a razão, em sentido estrito e filosófico, só pode influenciar nossa conduta de duas maneiras: despertando uma paixão ao nos informar sobre a existência de alguma coisa que é um objeto próprio dessa paixão, ou descobrindo a conexão de causas e efeitos, de modo a nos dar meios de exercer uma paixão qualquer" (Hume, 2009, p. 499). 
pura natureza e as peculiares experiências, sem atribui maior importância a uma ou a outras no que diz respeito à formação do indivíduo.

Resta-nos considerar, por fim, o modo como Hume encara o(s) indivíduo(s) de quem fala. Nesse quesito, a questão da simpatia é fundamental. Seja a simpatia no seu parentesco com a faculdade de raciocinar ou julgar, seja a simpatia como aquilo que identifica um homem a outro homem e que faz o universo do indivíduo falado não se restringir a si próprio, ou seja, como instância mediadora do raciocínio e do julgamento. Dito isso, nos parece interessante a interpretação de que Hume não seria um empirista radical solipsista (que fala só de si mesmo), mas teria uma teoria psicológica, visto que de acordo com essa teoria as definições de "bom" ou "mau" relacionam as impressões primárias com hábitos estabelecidos socialmente e estados mentais derivados de redes de simpatia. A questão que se colocaria, por conseguinte, é se essa teoria psicológica seria subjetivista (e relativista) ou teria um fundamento objetivo, e de que tipo de objetividade se trataria. Conte (2006) vai apresentar defensores de todas essas leituras possíveis. Particularmente interessante, é a recusa do mero subjetivismo. ${ }^{10}$

Contudo, a tese do objetivismo, chamemos "puro", pode carregar justamente a noção que consideramos ruim de uma natureza humana eterna e imutável, que é de fato bastante presente em Hume, como, por exemplo, quando observa que no estudo dos "[...] sentimentos, inclinações e gênero [...]" de um povo a "[...] maioria das observações [...]" podem ser repassadas para outros povos sem prejuízo para o entendimento (Hume, 1999 apud Conte, 2006, p. 140). Essa objetificação pode levar, a nosso ver, a uma posição no mínimo ingênua e no máximo perigosa se acreditarmos que é possível um conhecimento perfeito dos fatos e uma imparcialidade perfeita dos sujeitos ${ }^{11}$.

Mas há, segundo Conte (2006), outras alternativas à leitura de que Hume não é um subjetivista, dado que não defende que "[...] a distinção entre virtude e vício é meramente uma distinção subjetiva ou baseada em fatores psicológicos privados [...]" (Norton, 1995, p. 156). Seriam elas o "realismo", muito enfático na defesa de uma objetividade fundada na existência prévia, externa, de valores morais compartilhados pelos indivíduos ${ }^{12}$, e o "intersubjetivismo", que teria vantagens sobre

(10) Dada a economia de nosso texto, remetemos o leitor aqui para Conte (2006).

(11) Como o próprio Hume que, por vezes, parece acreditar que "[...] sob certas condições, se nós tivéssemos um conhecimento perfeito de todos os fatos, e olhássemos todos os fatos de um ponto de vista objetivo, nossos sentimentos comuns nos levariam a um padrão similar de julgamento moral e todos chegaríamos às mesmas distinções morais. Um ponto de vista objetivo seria a perspectiva de um agente que pudesse sair de sua 'situação privada e particular', abstraindo situações e sentimentos pessoais particulares para alcançar uma perspectiva imparcial" (Conte, 2006, p. 139).

(12) Em que, "Virtude e vício [...] seriam 'descobertos' por nossa consciência, não 'criados' por ela". (Conte, 2006, p. 142). 
o realismo, em que não há uma existência prévia do que é compartilhado, mas uma sua recriação permanente, pois, segundo o próprio Hume:

[...] 'as mentes dos homens são como espelhos uma das outras' em que 'cada uma reflete as emoções das demais' e 'as paixões, sentimentos e opiniões podem se irradiar e reverberar várias vezes', de modo que constituímos o mundo como um mundo partilhado, ainda que todos tenhamos experiência dele a partir de perspectivas diferentes (Conte, 2006, p. 145).

Isso seria quase apontar para uma natureza que inventa o hábito, o qual se redescobre inventando a natureza - com especial ênfase para os assuntos morais. Isso porque, como diz Kiraly (2010b, p. 199): “[...] a natureza humana se habitua à experiência que a constitui. Nesse processo a imaginação estabelece conjunções constantes entre ideias e fenômenos que reconhece. Em última instância a natureza humana, pelo hábito, inventa a experiência que a constitui”. Isso quer dizer, para nós, que só o que é da natureza é então se adaptar. E, no processo de adaptação, ainda inventamos que há uma natureza, que esta seria estável e mesmo imutável, o que não temos a menor condição de afirmar, mas temos necessidade de afirmar. Logo, segundo Hume, o que seria da natureza é carecermos pensar assim.

Em suma, observamos que há em Hume uma abertura de interpretação, que parece clara no Tratado da Natureza Humana, que indica que os homens seriam por natureza (imutável) apenas capazes de processar sensações, como a sensação de proximidade, identidade ou simpatia, cuja forma e conteúdo (mutável) vão sendo construídos intersubjetivamente - conteúdo moral que afeta as ações. O que percebemos a partir de nossos sentidos, o como o percebemos e julgamos, muda. Sobre o que a necessidade de proximidade irá atuar, é capaz de mudança. A questão é que se introduz então todo o mundo da representação em geral (e da linguagem em particular) que, se Hume já intuía naquilo que afirma de que as ideias se ligam às sensações pela imaginação, só vai avançar com a filosofia (e a psicanálise) do século $\mathrm{XX}^{13}$. Assim, se temos por natureza a capacidade de sentir e julgar o que é bom, aprazível, podemos dizer com Cerqueira (2006, p. 8) que o senso da virtude, é da natureza, mas as "[...] virtudes artificiais evoluíram ao longo da história com base na natureza humana e nas relações interpessoais", portanto, vamos, junto com nossos contemporâneos, por meio da nossa própria imaginação, mas também por meio de todo um universo de representações que compartilhamos, criando virtudes outras, como o que é o justo ou o belo. Da natureza mesmo restaria apenas "[...] nossa propensão a simpatizar com os outros e a receber por comunicação suas inclinações

(13) Por isso, diz Kiraly ser Hume um dos pilares da modernidade junto com Kant/Weber de um lado e Hegel/Marx de outro. Por isso, ele, mesmo sem ser um filósofo da linguagem, “[...] inaugura a preocupação com as regras e com as convenções que afetará a filosofia analítica” (Kiraly, 2010b, p. 198). Mas, no que nos diz respeito aqui, o mais interessante dessas releituras de Hume é apontarem para que, em sua obra, “o sujeito é relevante, mas a sua soberania é relativa" (Kiraly, 2010b, p. 199, grifo nosso). 
e sentimentos, por mais diferentes ou até contrários aos nossos” (Hume, 2009, p. 351).

\section{A implosão da divisão natural e artificial na sympathy de Smith}

Daqui para frente veremos como para Adam Smith (1723-1790) tais conclusões serão ainda mais radicalizadas. Para tanto, consideramos que muitos são os pesquisadores que desde há muito, e ainda hoje, se debruçam sobre sua obra Teoria dos sentimentos morais (TSM), cujas teses seriam vistas, ora como afins, ora como incongruentes, com sua A riqueza das nações $(\mathrm{RN}) .{ }^{14}$ Justamente por isso, podemos abrir mão de apresentarmos a TSM também nós ${ }^{15}$ e recorreremos à obra apenas quando necessário para a compreensão do nosso ponto central: o que é o indivíduo e em que medida seu comportamento se deve a uma pretensa "natureza humana". Assim sendo, damos seguimento a partir do ponto em que chegamos com Hume - que é a conclusão de muitos especialistas no pensamento filosófico de Smith, que salientam que este não defendia ser a moralidade nem algo natural aos homens, nem artifício por estes criado para controlar suas paixões; isso porque ele implodia com "[...] a linha divisória entre natureza e artifício" (Cerqueira, 2006, p. 13) de modo ainda mais radical que Hume:

Radicalizando o argumento de Hume, Smith argumentou que não apenas a justiça, mas o conjunto da moralidade sobrevém à natureza humana de uma maneira semelhante àquela descrita por Hume ao explicar o surgimento da justiça. Neste sentido, Smith rejeita a distinção entre virtudes naturais e artificiais e associa intimamente a moralidade à sociabilidade (Cerqueira, 2006, p. 13).

Ou, ainda, Haakonssen (e quase nos mesmos termos de uma leitura intersubjetivista de Hume):

Pode-se dizer que Smith sugeriu que a moralidade em geral era "artificial" mas que ela era um artifício que, por assim dizer, era "natural" para a humanidade. [...] No âmago do complexo argumento de Smith estava a ideia de que a personalidade das pessoas, sua habilidade de serem agentes autoconscientes vis-à-vis outras pessoas e vis-à-vis a seu próprio eu passado e futuro, era algo adquirido no intercurso com os outros (Hakonssen, 2003, p. 211-212).

Isso significa que é insuficiente a compreensão de que a natureza nos dotou de um sentido de identificação com o outro que seria base do comportamento social, incluindo os julgamentos morais, como o faz o próprio Smith nas primeiras linhas da TSM: "Por mais egoísta que se suponha o homem, evidentemente há alguns

(14) Por exemplo, Campbel (1975); Evensky (1989); Haakonssen (2002, 2003) e Fleischacker (2004).

(15) Para tanto, ver Ganem (1999); Cerqueira (2006) ou Passos (2006). 
princípios em sua natureza que o fazem interessar-se pela sorte de outros, e considerar a felicidade deles necessária para si mesmo, embora nada extraia disso senão o prazer de assistir a ela" (Smith, 1999, p. 5).

Mas veremos como o próprio Smith vai, além disso, respondendo, senão todas, ao menos algumas das questões que nos surgem. Assim, e considerando que a capacidade de nos importarmos com o outro é um dom "natural", como opera essa "sympathy"? ${ }^{16}$ Quais seus conteúdos concretos em cada tempo e lugar? Como são apropriados pelo conjunto dos indivíduos (ou como são distintamente apropriados por estes)? Como são herdados de uma época a outra? E até, é possível tomar consciência crítica dos mesmos? Essas questões estão no horizonte da filosofia moral dos nossos pensadores, mas apenas ligeiramente desenhadas.

É sabido que Hume e Smith substituem o "desejo de glória" - que coloca os homens em guerra fratricida em Hobbes - pelo "desejo do ganho" - que acaba por instituir uma certa harmonia entre eles. Esse desejo do ganho é universal. Mas se mantemos o que tínhamos concluído, esse caráter de universalidade não necessariamente torna o desejo de ganho algo natural. Ele faz parte, isso sim, dos conteúdos que qualificam a simpatia/identificação - no mais, mecanismo concreto da universalização de um dado comportamento. Por isso mesmo, como diz Ganem (1999, p. 4), Smith compreende "[...] em toda a extensão e complexidade [...]", a solução hobbesiana da emergência da ordem pelo contrato - conteúdo da ordem mercantil, diríamos nós, nem sempre compreendido pelos que veem na "mão invisível" do mercado mais um conjunto de vetores matemáticos do que um conjunto de normas e instituições. O que estamos salientando é que há uma combinação prévia entre os indivíduos em Smith, sua base é a de que todos devem se especializar e assim trocar entre todos. Desde logo, os homens não seriam naturalmente egoístas, mas naturalmente "tendentes às trocas", o que compactua com a noção de ser naturalmente tendentes a se ver nos outros ${ }^{17}$.

(16) Quer nos parecer que o sentido em português da palavra sympathy, como Smith a utiliza, cobre tanto o significado de simpatia quanto o de empatia, principalmente se entendermos o primeiro como mais ligado a uma dimensão afetiva (ou às paixões, como fala Smith) e o segundo, a uma dimensão cognitiva. Assim é que há algo de cognitivo no modo como podemos nos colocar no lugar do outro, nos imaginando a nós mesmos nesse lugar. Para se ter uma ideia, esse espelhamento é usado nas pesquisas das neurociências atuais como demarcador de níveis de inteligência entre os animais. Na mesma linha da nossa reflexão, mostrando que a simpatia nada tem a ver com benevolência, uma vez que contém mesmo a inveja - confirmando a nossa impressão de que empatia capta melhor essas dimensões de identificação de um no outro, mais que doação de sentimentos de um - ver Dupuy (1992) e Morrow (1923).

(17) Por isso mesmo não acreditamos haver descompasso entre a TSM e a RN, ligadas ambas por um único axioma. Como diz Vernon (1998, p. 3): “[...] Adam Smith's single axiom ['the propensity to truck, barter, and exchange one thing for another'], broadly interpreted [...] is sufficient to characterize a major portion of the human social and cultural enterprise. It explains why human nature appears to be simultaneously self-regarding and otherregarding". 
Vejamos mais de perto, então, o que é essa capacidade de simpatia, base de toda essa construção em Smith. Ele a esclarece como o nosso sentimento de companheirismo com qualquer paixão. Mas um sentimento que exige uma mediação: a tentativa do expectador por se colocar na perspectiva daquele que sofre diretamente a dor ou prazer, e que é a responsável pela criação de um "eu imaginário" - base diante do "expectador imparcial", quando se passar da solidariedade primária ao julgamento moral. Mas, ainda, para que essa operação seja possível, exige-se certo conhecimento e reconhecimento ou compartilhamento da causa geradora. Quanto mais interpessoais as paixões (como a raiva entre os indivíduos), mais é requerido um compartilhamento de contextos para uma resposta simpática forte. Por sua vez, o julgamento moral só pode se dar a posteriori, não podendo descender naturalmente da solidariedade mesma, sentida a priori. Enquanto o julgamento depende de convenções sociais mais ou menos elevadas acima da base natural, a solidariedade sustenta essa base, como sintetiza o próprio Smith:

\begin{abstract}
Primeiro, simpatizamos com os motivos do agente; segundo, participamos da gratidão dos que recebem benefício de suas ações; terceiro, observamos que sua conduta obedece às regras gerais por meio das quais essas duas simpatias geralmente agem; e, por último, se considerarmos tais ações como parte de um sistema de conduta que tende a promover a felicidade do indivíduo ou da sociedade, então dessa utilidade poderá resultar certa beleza, não muito distinta da que atribuímos a qualquer máquina bem engendrada (Smith, 1999, p. 406).
\end{abstract}

Assim como Hume, Smith não vê na simpatia nenhum princípio utilitário atuante, uma vez que podemos simpatizar e torcer por heróis de romances ou tragédias que jamais teriam alguma ligação utilitária que nos favorecesse no presente (ou futuro). A simpatia é somente uma capacidade de compartilhar sentimentos e que nada diz sobre os fins últimos da ação. Já a parcialidade que acompanha a simpatia em Hume é um tanto relativizada em Smith. Se esta se desenvolve via hábitos de observação, a experiência fornece também material para reflexões imparciais - motivadoras de condutas em consonância com uma existência virtual (imaginária) do eu. Assim, se Hume parte de uma abordagem utilitária para só então resgatar a simpatia como "fonte da aprovação moral", ${ }^{18}$ Smith, ao contrário, não pode diferenciar as ações motivadas por interesses próprios das ações motivadas por influência simpática, porque os interesses dos primeiros estão necessariamente mesclados com os interesses da sociedade. A virtude, assim como o vício, deve

(18) Como dirá Hume, o princípio de simpatia “[...] é fraco demais para controlar nossas paixões; mas tem força suficiente para influenciar nosso gosto, e para nos dar os sentimentos de aprovação ou de condenação" (Hume, 2009, p. 540, grifo nosso). 
provir originalmente do senso de conveniência e não da percepção de um prazer ou uma dor ${ }^{19}$.

Fruto da reflexão simpática de sua paixão no outro, a paixão dominada e posta em concordância com a visão do expectador deve conduzir o indivíduo ao comportamento virtuoso, tendo em vista que, para o expectador, a paixão que lhe é alheia não pode ser sentida de todo vigor, senão de modo fraco e não diferente entre a satisfação presente ou futura. O reconhecimento do esforço da contenção da paixão presente será assim digno de aplauso pelo expectador. Esse comportamento não caracteriza tão somente uma troca de utilidade presente por uma utilidade futura, mas também um princípio de ação reconhecido e desejado internamente. Daí o comentário de Cerqueira (2006, p. 17), de que em Smith "[...] cada indivíduo tem em si um motivo para observar as normas de comportamento adequadas".

Dessa comparação se evidencia que em Smith é impossível um indivíduo exclusivamente voltado à busca de prazer e ao afastamento da dor, uma vez que esses dois princípios comportam seu contrário imaginário, portanto, construído pelo externo. Passar por cima do sentimento simpático, para Hume, é uma questão de pesagem utilitária e, para Smith, é uma questão de imposição imaginária, uma vez que o indivíduo aqui (desde que inserido em sociedade) não só é julgado por uma jurisdição externa, ou seja, a população em geral que lhe pode censurar - tão logo o fato apareça ao conhecimento do público - como também é julgado inevitavelmente por uma jurisdição interna, fundada na experiência, que faz o indivíduo ser avesso a todo comportamento censurável, ou seja, por princípio censurável. Smith chama o juiz interno dessa jurisdição de "expectador imparcial”, ou, ainda, o "[...] grande morador do peito, grande juiz e árbitro da conduta" (Smith, 1999, p. 328). Tendo os olhos para esse "segundo tribunal", Smith pode afirmar que

[...] naturalmente o homem não apenas deseja ser amado, mas amável; ou ser objeto natural e apropriado de amor. Naturalmente não apenas teme ser odiado, mas ser odioso; ou ser objeto natural e apropriado de ódio. Não deseja apenas louvor, mas o que é digno de louvor; ou, ainda que não louvado por ninguém, ser objeto natural e apropriado de louvor. Tem horror não apenas à censura, mas ao que é digno de censura; ou, embora ninguém o censure, ser, contudo, objeto natural e apropriado de censura (Smith, 1999, p. 143).

Tudo isso significa que ao mesmo tempo que o indivíduo é a medida de todas as coisas (funcionando como juiz externo), a sociedade experimentada por ele, e ainda por seus antepassados, é a medida da qual ele parte para fazer seu julgamento

(19) Smith poderia mesmo dizer que "A mais heroica bravura pode ser empregada indiferentemente, ou na causa da justiça, ou da injustiça [...] Nessa e em todas as demais virtudes do autodomínio, a qualidade esplêndida e deslumbrante parece ser sempre a grandeza e constância do empenho, e o forte senso de conveniência necessário para fazer e manter esse empenho. Muitas vezes os efeitos são porém muito pouco considerados" (Smith, 1999, p. 330). 
(juiz interno). Os dois juízes devem ser concordantes - a não ser em casos especiais quando um julgamento é deslocado de seu plano verídico (exemplo: acusação sobre um inocente) ou quando a experiência é radicalmente transformada em outro tipo (exemplo: o homem solitário e isolado que se confronta com a sociedade). Ao dizer que "[...] empenhamo-nos em examinar nossa própria conduta como imaginamos que outro expectador imparcial e leal a faria" (Smith, 1999, p. 140), Smith deriva sua ideia do autodomínio: o homem que se tornou social reconhece, nos outros, as suas próprias paixões, que, por sua vez, serão alvo de censura ou louvor, direcionando-os assim àquele comportamento comedido e virtuoso, aceito por não ferir e nem abusar dos sentimentos simpáticos que todos nós possuímos e gerimos, permitindo o convívio entre diferentes. Qualquer destoar de solidariedade adequada, a depender dos tipos de paixões prazerosas ou dolorosas, insulta ou incomoda os expectadores ou os indivíduos que sofrem com a paixão original. Aqueles, por não compartilharem de paixões alheias, e estes, por não comedirem suas paixões em nível razoável, serão reprovados. Porém,

[...] esse desejo de aprovação e essa aversão à desaprovação de seus irmãos não seriam suficientes para torná-lo adequado à sociedade para a qual fora criado. A natureza o dotou, pois, não apenas de um desejo de ser aprovado, mas de se tornar objeto de aprovação necessária, ou de ser aprovado pelo que ele mesmo aprova em outros homens. O primeiro desejo apenas o faria esperar mostrar-se adequado à sociedade. $\mathrm{O}$ segundo foi necessário a fim de fazê-lo preocupar-se em ser realmente adequado. O primeiro apenas poderia tê-lo motivado a afetar virtude e a ocultar o vício. O segundo foi necessário para inspirar-lhe o verdadeiro amor à virtude e o real horror ao vício. Em todo espírito esclarecido, esse segundo desejo parece ser o mais forte dos dois. Apenas os mais superficiais e mais fracos dos homens podem se deliciar com o louvor que sabem em tudo imerecido (Smith, 1999, p. 146-147, grifo nosso).

Nesse sentido, a natureza do homem possui princípios os quais direcionam seu julgamento para o outro, para, em seguida, refletir-se no nosso julgamento de nossa própria conduta, uma vez que na imaginação os motivos são tão fortes para evitar a censura quanto no real. Desse modo, enquanto o louvor direciona parte da decisão de ação, outra parte é direcionada pelo louvável, dado que o expectador imparcial reprime ameaçando com sentimentos não prazerosos (remorso) as ações censuráveis. Nesse sentido, a natureza humana é dupla:

O homem que deseja praticar ou realmente pratica uma ação louvável pode [...] desejar o louvor que é devido à ação, e às vezes talvez mais do que o devido. Nesse caso, os dois princípios (amor ao louvor e amor ao louvável) se mesclam um ao outro. Em que medida sua conduta foi determinada por um, e em que medida foi determinada pelo outro, eis o que o fundamento ele mesmo desconhece. Quase sempre os outros tampouco o sabem (Smith, 1999, p. 157158). 
Isso implica que Smith vê na conciliação entre indivíduo e sociedade a maior perfeição da natureza humana, em que os indivíduos são submetidos à prática constante e sob a necessidade permanente de visualizar seus atos e regulá-los por intermédio do expectador imparcial. De fato, eles quase se tornam esse expectador imparcial, e até mesmo quase sentem o que esse grande árbitro de suas condutas comanda que sintam (Smith, 1999). Por isso, por mais que o amor próprio contenha forças que sobrepujam outras paixões menos fortes, o direcionamento da ação para fins sociais benéficos estaria assegurado uma vez que as "regras dos homens" e os interesses do indivíduo devem se ajustar, pois esse ajuste é conforme à natureza. De fato, esse se parece com o melhor dos mundos, pois a natureza moral, além de direcionar a conduta econômica dos homens para o correto, não permite o descaso dos assuntos morais nos assuntos econômicos e ainda castiga os sem moral:

Na corrida por riqueza, honras, e privilégios, poderá correr o mais que puder, tensionando cada membro e cada músculo, para superar todos seus competidores. Mas se empurra ou derruba qualquer um destes, a tolerância dos espectadores acaba de todo. É uma violação à equidade, que não podem aceitar (Smith, 1999, p. 104).

Por fim, importa lembrar que Smith estava consciente de que os hábitos podiam mudar, destruindo esse estado de coisas ideal. A super especialização oriunda dos progressos da divisão do trabalho, derivada por sua vez daquela competição conforme à natureza (e às regras de equidade) da situação anterior, pode levar ao embrutecimento, equivalente ao enfraquecimento do juiz externo e, assim, também, do juiz interno. Para que isso não ocorresse - assim como para que nossas paixões não tentassem demasiadamente nosso mandamento moral imparcial -, as regras gerais da justiça e do artifício deveriam guardar, sob último caso, o dever moral dos indivíduos, assim como na religião a figura ideal de expectador imparcial se faz presente pelos mesmos meios, como último recurso, apesar de também sofrer desvios.

Tais mudanças de hábitos e costumes aparecem também nas análises comparativas entre as nações. Quanto mais bárbaros os costumes e difícil a sobrevivência, mais fraca a simpatia entre os indivíduos - "Se nossa própria miséria nos agulha tão severamente, não temos vagar para cuidar da miséria alheia [...]" (Smith, 1999, p. 253). São as circunstâncias que possibilitam aos homens tanto perpetuar e reproduzir o embrutecimento quanto a polidez. O costume torna-se habitual e pode ser percebido, como muitos o chamam, de "[...] jeito do mundo, algo que pode ou deve ser praticado para impedir que sejamos logrados por nossa própria integridade" (Smith, 1999, p. 247). Em suma:

Toda época e país considera o grau de cada qualidade que habitualmente se encontra nos homens respeitáveis como o ponto médio do talento ou virtude particular, e, como isso varia conforme as diversas circunstâncias tornem 
diferentes qualidades mais ou menos habituais, por conseguinte variam os sentimentos relativos à exata conveniência de caráter e comportamento (Smith, 1999, p. 252).

Todavia, apesar dessa incrível capacidade de distorção dos sentimentos, jamais serão alvo de costume aquelas ações que contradizerem "[...] nossos sentimentos relativos ao estilo e caráter gerais da conduta e comportamento, do mesmo modo como os relativos à conveniência ou ilegitimidade de usos particulares [...] [se assim fosse] nenhuma sociedade poderia subsistir por um momento [...]" (Smith, 1999, p. 260). O mecanismo de aprovação e desaprovação, segundo a conveniência ou inconveniência da ação, permanece constante apesar das diferentes costumes e culturas, o que permite certa concordância de princípios morais, mas muita diferença entre as regras a depender dos níveis de satisfação das necessidades básicas, como a "[...] conservação e o estado saudável do corpo [...]" etc. (Smith, 1999, p. 265) -, muito embora essa busca primeira não apague a paixão pelo reconhecimento e pelo alcance de posição na sociedade.

Retomando os pontos principais da reflexão smithiniana, mas já apontando desdobramentos nossos que acreditamos em conformidade com o seu pensamento, diríamos que o mais importante a destacar é: a) se a capacidade humana de simpatizar com o outro é um dom da natureza, essa não é suficiente para fazer a natureza humana egoísta e autointeressada ou altruísta e benevolente; b) já o hábito, em conformidade com as condições objetivas e subjetivas de dada época e lugar, sim, é capaz de fazê-lo; c) a capacidade de simpatia, entendida em toda a sua dimensão de identificação com o outro via imaginação e sob o julgamento de um terceiro (expectador imparcial) reafirma, como diz Ganem (2002), uma incompletude ontológica (definidora, substancial) do homem; d) ou seja, antes de ser a princípio, dado, isolado, autossuficiente e sozinho, o indivíduo é a sua relação com o outro e se esse se vê dessa ou daquela maneira (inclusive quando o indivíduo se vê como algo dado, isolado e sozinho) é que as suas relações (intersubjetivas) o permitem; e) isso significa que, como dissemos atrás, há uma sociedade por trás do indivíduo em Smith, ou seja, a natural necessidade da aprovação do outro (explorada como vimos na TSM), bem como a natural necessidade de expansão das trocas (tão conhecida em $\mathrm{RN})$, não são um natural fora da história, mas são resultado mesmo desta.

Explorando um pouco mais o último ponto, o que estamos a dizer é que o ponto de partida de Smith é menos o indivíduo em si, digamos naturalizado, como "um da espécie", fora de qualquer consideração da sociedade, da cultura e da história, e mais uma possibilidade a partir desta. O aspecto de naturalidade (e mesmo harmonia) devém de uma generalidade, que Smith precisa corretamente em RN: a generalização das trocas, ou mais precisamente, o desenvolvimento da tendência 
humana às trocas ${ }^{20}$. E quer nos parecer que essa generalização das trocas econômicas anda de par com o igualitarismo (social e político) entre indivíduos, uma vez que o jogo de identificação, a partir da capacidade de simpatia (base da sua filosofia moral), é bastante ampliado nesse tipo de economia/sociedade. Ou seja, os indivíduos não são capazes de se colocar no lugar do outro por uma decisão pessoal e natural, mas moral, na medida em que moral implica o jogo de reconhecimento que vimos antes. Ou seja, se são capazes de fazê-lo, o são em determinada época em que isso se tornou um hábito e, mais que isso, uma necessidade. E acrescentaríamos um hábito possibilitado pela igualdade real (diria formal um marxista, sem negar, contudo, a radicalidade dessa igualdade vis a vis os outros tempos históricos) de posição dos homens na sociedade.

Está implícito nos parágrafos anteriores o quanto cremos que essa postura da filosofia moral smithiniana não está em desacordo com sua economia política, o que nos coloca ao lado daqueles que no debate Das Adam Smith problem defendem não a ruptura, mas a unidade entre a TSM e RN ${ }^{21}$. Ainda que tudo desta última obra se diz sobre a natureza egoísta e autointeressada do homem, só faz sentido se se ver esse comportamento como (contraditoriamente) natural em determinada época - a burguesa. A seguir veremos como em Bentham essa contradição há de se perder.

\section{0 abandono da simpatia intersubjetiva pelo cálculo "objetivo" em Bentham}

Jeremy Bentham (1748-1832) é reconhecido por muitos como primeiro desenvolvedor e principal expoente do pensamento utilitarista, aplicando seus princípios nos campos da moral e da política. Herdeiro de Hutcheson, como Hume e Smith, Bentham adota a máxima deste de que "[...] a melhor ação é a que proporciona a maior felicidade para o maior número de pessoas" (Magee, 2001 p. 183). Tal modo de pensar será condizente com sua ideia de moral fundamentada nos princípios utilitários que regem a natureza humana, em que apenas os pilares de dor e prazer sustentam as motivações individuais ou coletivas, em regra, a existência humana.

A princípio, a concepção de indivíduo em Bentham não parece muito distante das de Hume e Smith. Bentham também se considera um empirista que capta o seu objeto (o comportamento dos indivíduos) em sua experiência concreta, seus

(20) Ainda que chamar assim o resultado da tendência humana às trocas seja uma alteração possível apenas no linguajar marxista, não acreditamos que isso altere o significado de fundo na obra de Smith, apenas faz dialogar a sua denominação ao conceito de fato. Hegelianamente falando, isso se passa como se o conceito fosse maior e mais real que suas elucubrações por diferentes autores em suas obras ao longo da história, o que não o torna uma obra do espírito fora do mundo, mas no mundo. O conceito é o que ele vem a ser no somatório do diálogo entre todos e na lógica que tornou esse diálogo possível.

(21) Das Adam Smith Problem é como a escola histórica alemã chama essa questão da imbricação das duas obras smithianianas. Para uma exposição resumida da polêmica e uma defesa da posição unitária, ver Ganem (2002). Ver ainda os comentários feitos por Sen (2010) sobre o equívoco da visão do indivíduo smithiniano como egoísta e autointeressado. 
hábitos cotidianos. Também não rejeita os sentimentos derivados da simpatia, assim como não nega a existência de comportamentos altruístas. O que ele diz, contudo, é que estes constituem "termos ficcionais", os quais ele, com seu método, consegue associar aos "termos reais", dor e prazer"22. É esse método de Bentham que é capaz de separar a naturalidade (dos termos reais) e a artificialidade (dos termos ficcionais), divisão que vimos que havia sido implodida em Smith. Ou seja, em Bentham os construtos humanos práticos, nos quais são aplicados os princípios da moral (regras, obrigações, ética), são pertencentes ao que é demasiado volátil, e, se devem ser modificados de acordo com o princípio efetivamente natural-racional - sempre que a ponderação entre dor e prazer o exigir -, não são capazes de mudar nada neste, que permanece assim, fixo. E se, de um lado, a natureza é fixa e real, de outro, a sociedade ou comunidade é um corpo fictício: “A comunidade é um corpo fictício, composto de pessoas individuais que são considerados como seus membros constitutivos. O interesse da comunidade é, então, o quê? - A soma dos interesses dos diversos membros que a compõem" (Bentham, 1974, p. 4).

Interessante destacar de imediato que, sendo a comunidade apenas "soma das partes", não se requer nenhuma naturalidade para a comunidade de interesses, como a mão invisível de Smith. A harmonia entre todos é objeto apenas da artificialidade das formas de gestão do bem comum, construídas para limitar e mediar os excessos individuais que prejudiquem o bem-estar geral. Por isso, a missão dos governantes deve ser punir e recompensar (ou seja, gerar prazer e dor) de modo a proporcionar o máximo de felicidade para a sociedade, não submetendo impositivamente a definição de prazer dos indivíduos, mas antes reforçando as escolhas racionais individuais dos agentes no que tange ao comportamento otimizador. Daí:

[...] o objetivo geral que caracteriza todas as leis - ou que deveria caracterizálas - consiste em aumentar a felicidade global da coletividade; portanto, visam elas em primeiro lugar a excluir, na medida do possível, tudo o que tende a diminuir tal felicidade, ou seja, tudo o que é pernicioso (Bentham, 1974, p. 60).

A harmonia entre indivíduo e sociedade vem assim de seguirem, a ética pública e a privada, a mesma norma calculadora da busca da maior felicidade, maximização do prazer de todos e de si. Desse modo, a ética pública se reserva à análise da natureza dos indivíduos, tendo por objetivo "construir o edifício da felicidade através da razão e da lei”, mas, onde a esfera pública é definida como ficcional, o Estado deveria ser pouco influente. Em termos bastante resumidos, o indivíduo é definido por Bentham como aquele

(22) Ou seja, “[...] a explicação dos termos ficcionais deve, em todos os casos, manter uma relação com os termos reais, para que as consequências dos primeiros termos possam ser traduzidas pelas consequências dos segundos" (Dias, 2013, p. 9). 
a) que busca o prazer e foge da dor, pois esta é uma característica da sua natureza; b) além disso, ele é a entidade ontológica fundamental para análise política, pois é o único que possui existência na realidade, sendo que as sensações que busca também são denominadas sensações reais; e c) possui uma razão denominada razão calculadora que prevê as consequências das ações (Dias, 2012, p. 489).

Apesar disso, vejamos como o autor chega a essas simplificações. Os indivíduos querem por natureza sobreviver, querem o maior bem para si, mas, também conforme Bentham, querem ser amados por outros e querem estimar-se a si próprio. Essa compreensão é dada de imediato para o indivíduo que sofre a falta de qualquer desses elementos. É esse mesmo sofrimento que o leva a se solidarizar, com mais vigor e com mais constância, por si mesmo. Seria muito difícil (ou conflituoso, sofrido) fazer uma avaliação que não fosse viesada por seus próprios interesses. ${ }^{23}$ Sendo assim, no lugar de um terceiro, um expectador imparcial com quem o "eu" possa dialogar e mesmo se apaziguar, o que tem lugar em Bentham é que na maioria dos comportamentos os reais motivos da ação sofrem recalque pelo próprio agente, tendo em vista adequar-se à moral vigente e a sua própria estima. Logo, a compatibilização entre o melhor para si e a busca da estima do outro só é possível à base do conflito entre meus motivos e minha estima, em que o indivíduo toma como máxima "o maior bem para mim mesmo" e a moral fala "o maior bem para o maior número de pessoas". Daí que uma sobreposição completa entre elas é sempre improvável e requereria uma perfeita estruturação da sociedade, entre governantes e governados. Ou ainda, requereria uma hipótese irrealista na qual uma sociedade só seria composta por homens de elevada educação e refinamento capazes de harmonizar seus interesses à norma moral. Logo, para Bentham seria prudente para a orientação das ciências econômicas e do governo tomar o homem médio, autointeressado, como regra geral do comportamento humano ${ }^{24}$.

Dessa forma, Bentham, instrumentalmente, simplifica a natureza humana de maneira a retirar todo tipo de variações (inclusive as de tempo e lugar) para dispor o indivíduo como vetor utilitário frente ao bem absoluto. Fora a angústia de cada um frente a sua escolha moral versus particular, os indivíduos não comungam de nenhum processo de identificação (como em Smith) e nem de comunhão de hábitos locaistemporais (Smith e Hume). Nesse universo reina apenas o princípio de utilidade como guia comum da ação natural.

(23) Ressaltamos que a mesma observação também é feita por Smith, mas que em seu discurso a vontade individual autônoma só representa parte do reconhecimento de vontade total do indivíduo e não contém viés preponderante ou capacidade de observar o autointeresse em si.

(24) Assim, se querermos falar em natureza humana egoísta conforme Bentham, temos de falar de natureza em termos de probabilidade, de algo como sendo "somente" o mais comum. No entanto, desde já é possível notar como Bentham isola o "eu" da constituição moral, sua função no desenvolvimento subjetivo, tendo esta que ser passada externamente via educação. 
Nota-se como Bentham, procurando se antecipar a qualquer consideração histórica das valorações, encontra no princípio utilitarista uma base neutra (e positiva), um fundamento extrínseco para o julgamento humano, chegando ao oposto, a uma posição normativa. Isso por afirmar que a moral deve idealmente (ou seja, para todas as épocas) basear-se unicamente no princípio da utilidade, pois podemos sempre afirmar que a ação conforme esse princípio "[...] deve ser praticada, ou, no mínimo, que não é proibido praticá-la [...]” (Bentham, 1974, p. 11).

Bentham se afasta assim de toda verdade construída na história. Para ele, toda verdade moral percebida como mutável é inverdade. Nesse caso, as aberturas à história que vimos em Hume e Smith seriam meras imprecisões. E mais, na impossibilidade de derivar de seus sistemas um princípio universal das ações, Bentham critica que nestes autores "[...] a aprovação ou a reprovação constituem uma razão suficiente em si mesma” (Bentham, 1974, p. 15).

Mas voltando ao princípio utilitarista, como víamos, este funciona porque costura os indivíduos e seu autointeresse com algo que os limita (desde fora), mas cujo funcionamento é pautado pelo mesmo princípio. Ou seja, se não há um espaço para o julgamento moral de um terceiro que não eu e o outro (terceiro este que não é imune aos hábitos e costumes), há apenas o regime de punições imposto pelo governo para refrear os abusos (com penas duras, mas nem tanto que criem um sofrimento inútil). ${ }^{25}$ Se um sistema moral com base no princípio da simpatia é variável demais para o estabelecimento de regras gerais, leis e consequentes estatutos de punição, o princípio de utilidade, sim, possui a capacidade racional e a amplitude universal para abarcar um sistema geral, político e jurídico, sem distorções provocadas por valores culturais, gostos ou por demais deformações entre a hierarquia entre os indivíduos.

Isso implica reconhecer que o princípio de maior felicidade para o maior número de pessoas deve seguir ainda outra máxima: "Cada um deve ser contado como um, e ninguém como mais de um [...]” (Magee, 2001, p. 184), o que significa que Bentham não está fundamentando a moral - nas suas diversas formas e funções históricas - mas, sim, purificando-a de digressões parciais e, assim, tornando consciente um modelo ideal prático a ser seguido como único princípio moral universal confiável. Ou seja, está sendo puramente normativo. Bentham escreve:

O único fundamento correto da ação é, em última análise, a consideração da utilidade, a qual, se for um princípio correto da ação e da aprovação em um determinado caso, sê-lo-á em todos. Muitos outros princípios - ou seja, outros motivos - podem constituir a razão que explica por que esta ou aquela ação foi praticada, porém a utilidade constitui a única razão que explica por que a

(25) Aí está umas das críticas do autor ao sistema moral baseado no princípio da simpatia e da antipatia, pois “[...] esse tende ao máximo a pecar por severidade excessiva [...]” (Bentham, 1974, p. 16). 
mencionada ação pode (moralmente) ou deve ser praticada. A antipatia ou o ressentimento sempre necessitam ser regulados, para evitar que façam o mal. Ser regulados por quem e por quê? Sempre pelo princípio da utilidade. Entretanto, o princípio da utilidade não necessita nem admite outra norma reguladora além de si mesmo (Bentham, 1974, p. 18, grifos do autor).

Dessa forma, Bentham não nega a influência das circunstâncias sobre qualquer evento que mereça punição, ao contrário, afirma que “[...] em certas circunstâncias até o matar uma pessoa pode constituir um ato benéfico, ao passo que em outras pode constituir fato pernicioso o simples oferecer alimento a uma pessoa" (Bentham, 1974, p 26). Esse tipo de posicionamento guia a argumentação do autor até a defesa de uma reforma psicológica profunda, onde os indivíduos despertariam de um contexto moral irracional (derivado das religiões) dado que todo processo de culpabilização baseado em costumes e hábitos teria de ser afastado do interior dos sujeitos em prol daquilo que verdadeiramente embasaria a moral, ou seja, as consequências maximizantes da utilidade derivadas da ação. Uma sociedade que só poderia ser assim idealmente concebida, distante de todo sistema de crenças (valoração da instituição da família etc.), e distante das internalizações distintas das noções de bem e de mau que poderiam comprometer a avaliação das ações que visariam um resultado objetivamente benéfico para a sociedade (E.g.: antes cinco vidas salvas que a única vida de meu filho).

Esse tipo de raciocínio não faz outra coisa, na realidade, que universalizar o princípio de utilidade de modo a tentar abarcar valores e culturas diversas, caindo em uma abstração extrema (podendo mesmo ser criticada por incitar resultados imorais - dado um sistema de crenças circunstancial). $\mathrm{O}$ significado do ato jamais pode assim ser compreendido em sua mudança na relação com a totalidade na qual se insere, o que em tese desqualificaria um julgamento objetivo com vistas à maximização do bem-estar geral como princípio correto de política e de punição. Suas bases, portanto, não compreendem as circunstâncias reais porque se voltam unicamente para o indivíduo que, por isso, tende a ser perdido mediante as abstrações gerais que não podem captar a construção como mudança qualitativa do mesmo. Assim, a tentativa utilitarista ao subjetivar as razões e objetivar as consequências, não percebe que as razões são objetivas, constructos de base mutante, e que as consequências ao serem objetivadas, com o objetivo de dispor a maior felicidade para o maior número de pessoas, podem ser arbitrárias - ou tendenciosas assim como a moral baseada na simpatia o seria - em função da primeira deficiência. As circunstâncias reais não podem ser compreendidas quando se parte da igualdade e homogeneidade social entre indivíduos abstratos. Tal método, ao contrário do que pretende ter como finalidade, a saber, a justiça universal, não mais manipulada ou desvirtuada de sua real função, consegue fazer o oposto que desejava ao desfazer as diferenças entre os homens, não compreendendo assim que as circunstâncias não 
devem ser negadas por um princípio universal justo, mas antes compreendidas em suas contradições, conflitos e significados históricos.

Por fim, não podemos encerrar a discussão da compreensão do que há de natural na concepção benthaniana do indivíduo sem que consideremos a sua discussão acerca dos motivos da ação, em que há, como vimos no início da seção, um conflito entre a natureza passional e a racional-moral. Partimos do pressuposto de que esse conflito em Bentham não está dado entre opostos - do contrário todo princípio moral seria entendido como absurdo. Justo para compreender tal aproximação é que se faz necessário averiguar os diferentes tipos de motivos, pois nesse ponto se encontram as relações entre o indivíduo e os demais membros da comunidade. Tais motivos são distribuídos por Bentham entre: a) sociais - boa vontade ou benevolência, amor à reputação, desejo de amizade, religião; b) dissociais - desgosto ou descontentamento; c) pessoais - desejo físico, interesse pecuniário, amor ao poder, autopreservação, incluídos o temor das dores dos sentidos, o amor ao sossego e o amor à vida (Bentham, 1974, p. 48).

Dentre os motivos sociais, contudo, apenas o da boa vontade reproduziria fielmente as ações de acordo com o princípio moral de utilidade. Dentre as demais, a que mais tange o princípio de utilidade (moral) é o do amor à reputação. Sua incompleta correspondência advém do fato de que indivíduos, ao formarem sua compreensão de mundo e, por conseguinte, ao interpretarem diferentemente o sentido de justiça, agem muitas vezes segundo os princípios da simpatia/antipatia e do ascetismo. Agem segundo um sistema de crenças não correspondente à razão utilitária. Como entende Bentham, o amor à reputação é dirigido tanto ao visar do público quanto a si mesmo, contudo, ainda atrelado indiretamente ao sentimento de aversão à censura, ou seja, via hábito ou aversão ao desenvolvimento de um que seja censurável. Em ambos os casos o indivíduo que considera sua reputação o faz em um quadro de isolamento e solidão, no qual abstrai a si de uma identidade intersubjetiva.

Nota-se a diferença entre a argumentação de Bentham sobre a benevolência e o "querer ser amável" de Smith. Neste, a consideração moral é naturalizada (mas, como vimos, porque herdada das circunstâncias), quase não raciocinada e sim interiorizada nos seus aspectos gerais, sendo assim também dificilmente manipulada ou ensinada. Se se quer atuar sobre a benevolência, há que se alterar as condições objetivas nas quais os indivíduos estão postos (para que a sua verdadeira natureza possa se desenvolver). Essas teses são refutadas por Bentham, que acredita ter descoberto o princípio moral imparcial, através do exercício da razão, que nega o alcance da imparcialidade para o homem médio assim como nega o senso de justiça inato. Isso se passa porque, em Smith, ao contrário de Bentham, o "eu” só é em parte um eu individual, que ainda desconhece grande parte do que seja o seu querer, e cujo julgar diz respeito àquela parte de si que participa do eu social que é o espectador imparcial. Por essas vias, Smith entende que um ato que agrida a sociedade - mesmo 
em sua ausência - agride o próprio agressor, porque o desvirtua da imagem que faz de si (a única que possui como indivíduo concreto). Ou seja, o aprofundamento dos níveis de consciência que tem lugar quando se abre o raciocínio entre indivíduos inviabiliza as significações práticas da utilidade racional.

Feitas essas observações, fica mais claro que o conflito existente entre natureza passional e racional-moral em Bentham se dá num mesmo terreno, o da individualidade sem sociabilidade. Por onde não se compreende bem a necessidade de um agir moral por parte do indivíduo, senão através de um amor à reputação, agregada ao esclarecimento do saber de uma visão de mundo racional-utilitarista, o que é exterior, pois não decorre naturalmente, à condição, desenvolvimento e constituição afetiva dos sujeitos. Um conflito entre os motivos de autopreservação (disposição sobre a felicidade própria) e os motivos de boa vontade ou benevolência (disposição sobre a felicidade dos outros) deve, por conseguinte, ser vencido pelo primeiro sobre a maior parte da vida de um homem, sob a ameaça de extinção da espécie, entendendo o motivo da autopreservação como um motivo ideal entre o conjunto de motivos pessoais. Assim, Bentham poderá dizer:

Cuál es el idioma de la verdad sencilla? Que a pesar de todo lo que se ha dicho, el predominio general de la propia estimación sobre cualquiera otra clase de consideración, queda demostrado por todo lo que se ha hecho: o sea, que en el curso ordinario de la vida, en los sentimientos de los seres humanos de tipo común, el yo lo es todo, comparado con el cual, las demás personas, agregadas a todas las cosas juntas, no valen nada; y eso, aceptando, como quizás pueda serlo, que en un estado de extrema madurez de la sociedad se pueda encontrar, de vez en cuando, una mente vastísima cultura y de amplitud de miras que, bajo el influjo de un estímulo extraordinario, haga el sacrificio del interés de su propia consideración en aras del interés social, en escala nacional; de esto no ha dejado de haber algún ejemplo; la virtud pública de esta naturaleza, razonablemente no puede considerarse, porque se toma mиy frecuentemente como ejemplo de locura (Bentham, 1965, p. 12).

Pois é esse mesmo princípio, o do interesse pessoal, apenas aparentemente empírico, positivo e rigoroso, que Bentham entende ser uma base firme para a ciência econômica recém nascida: "[...] el sistema de economía que se construya sobre cualquiera otra base, se edifica sobre una base falsa" (Bentham, 1965, p. 13).

\section{Conclusão}

Como dissemos na introdução deste trabalho, o papel do indivíduo na economia é basilar para a construção dessa ciência desde seus primórdios (com Hume e Smith) até os atuais sofisticados modelos neoclássicos, passando mesmo pela discussão marxista (nem que seja evidenciando, na sua ausência, um ponto cego). Como diz Paulani (1996), sem o indivíduo não haveria propensão à troca, 
preço de mercado girando em torno de preço natural, maximização sujeita a restrições, preferências reveladas, propensão a consumir e a poupar, decisões de investimento, demanda efetiva, antecipação racional de medidas de política econômica, progresso tecnológico, concorrência, crises, e [...] mercado (Paulani, 1996, p. 98). E acrescentaríamos, ainda, acumulação, fetiche e superação do capitalismo.

Contudo, as concepções acerca do que é o indivíduo não são ainda suficientemente claras pra nós. Assim é que, em Smith, por exemplo, e ao contrário do que afirma Paulani (1996), esse, em sua natureza autointeressada, não é, pelo menos não simplesmente, condição das trocas, mas resultado delas. Para nós, a famosa sentença de que "[...] não é da benevolência do açougueiro, do cervejeiro ou do padeiro que esperamos nosso jantar, mas da consideração que eles têm pelo seu próprio interesse" (Smith, 1996a, p. 74) não mostra que Smith assente a "[...] propensão natural à troca na consideração que cada um tem pelo seu próprio interesse" (Paulani, 1996, p. 98). Tudo o que vimos mostra como o interesse próprio não emerge de um indivíduo considerado isoladamente, mas do seu autorreconhecimento no outro com o qual convive. As trocas são assim, de certo modo, pressupostas a ele e não postas por ele. É porque há um desenvolvimento da divisão do trabalho que os hábitos mudam. É por causa da especialização posta como regra geral (no mercado) que o melhor é que cada um pense em si. E por isso pode mudar, pois Smith alerta que uma superespecialização do trabalho pode dar origem a hábitos perniciosos que levam ao embrutecimento, o que poderia tornar o autointeresse não mais naturalmente interessante.

Seria interessante seguirmos a conclusão de Paulani ao comentário sobre Smith, uma vez que concordamos integralmente:

Como poderia um ser humano atado a outros por relações de hierarquia e dependência pessoal lutar pelo seu próprio interesse? E como poderia fazê-lo se sua identidade fosse antes comunitária do que individualmente definida? No primeiro caso faltar-lhe-ia a igualdade; no segundo o direito privado de posse (Paulani, 1996, p. 98).

Certamente Smith não está respondendo a isso, não está fazendo como Marx, a gênese da economia que observa. O indivíduo que observa, por sua vez, não está mais sob o jugo dos laços de dependência pessoal, pois tem já uma identidade menos atrelada à comunidade, e já vigora a liberdade e a propriedade (ainda que formal, diria Marx). Todavia, Smith não está generalizando, como muitos depois dele, tais condições para um todo, o sempre natural. Se não há em Smith (e diríamos também em Hume) essa história com o "H" maiúsculo (de um materialismo histórico à la Marx, ou de uma história que devém dos avanços da pesquisa antropológica e histórica que bebem em outras metodologias), há, e esta é a primeira conclusão que apresentamos aqui, a história que não se opõe mais ao natural - não se concebe o 
indivíduo num núcleo rígido de ação (como vemos em Hobbes). As definições humenianas e smithinianas da natureza humana não são definições de uma natureza fora da história, mas de uma história limitada pelo escopo mesmo de sua observação.

A segunda conclusão que devemos marcar segue o raciocínio anterior, uma vez que poderíamos dizer que o comportamento utilitarista e a sua operacionalização pelo cálculo (tendo o dinheiro como elemento prático), como analisado por Bentham, também poderia ser defendido por ser o que havia de real e observável em sua época. ${ }^{26}$ Contudo, como mostramos, isso não é possível justo por Bentham fechar a porta à intersubjetividade e, decorrente desta, à construção de uma artificialidade (o terceiro que é o espectador imparcial) que se torna natural. Ou seja, o momento em que ele observa não tem qualquer conexão com outros, o que ele deseja de fato é se eximir dos relativismos (contradições) da história.

Por fim, há que comentarmos algo sobre a harmonia (intra e entre indivíduos) como condição natural da existência humana em Hume, Smith e Bentham. Se se pensar no indivíduo, a implosão entre o natural e o histórico em Smith e Hume é insuficiente para justificar a sua defesa, mesmo que parcial, da harmonia, vis a vis o conflito, como condição natural do homem. E aparentemente há certa agonia (mas não conflito) no indivíduo benthaniano. Isso porque, na fórmula humeniana e smithiniana, não é apenas o mercado que é o conciliador de interesses, mas há todo um processo de internalização do "Outro moral" (o que os psicanalistas chamam de o Superego) que os faz dividirem suas responsabilidades frente a própria construção da harmonia. Já em Bentham, os indivíduos vivem isolados na sua racionalidade utilitária (e ainda ameaçados, desde fora, por um grande Outro que pouco os conforta) e ao mercado deve caber a harmonização automática, ou seja, sem participação efetiva dos indivíduos. Se pensamos na harmonia sociedade/indivíduos, vemos que, enquanto é natural em Hume e Smith, é ontológica em Bentham, pois resulta de um princípio metodológico. No caso de Bentham, um governo contador, cuja ética pública consiste no cálculo da maior felicidade possível para a maior parte, é que coincide (mais que harmoniza) com um indivíduo contador, cuja ética privada consiste no cálculo da máxima felicidade possível para si. São suas metodologias que os aproximam.

Ocorre que as contradições para essa harmonia social serão mais gritantes em Bentham que em Hume e Smith. Bentham sabe que não basta ao governo a administração de regras e penas que limitem os abusos do autointeresse, pois, se os indivíduos se igualam na sua natureza hedonista, não são iguais na distribuição de seus talentos, e "[...] dado que os homens diferem entre si em capacidade e energia,

(26) Como, de resto, é o que mostra Marx com toda a sua análise do fetichismo n’o Capital, que não é um desmentido disso, mas um porquê disto, e mesmo as observações feitas no Manifesto Comunista acerca da substituição dos laços pessoais por laços monetários-financeiros. 
alguns obterão mais propriedade que outros" (Macpherson, 1978, p. 36). Daí, a civilização ser impossível sem "[...] a segurança da propriedade dos frutos do próprio trabalho". O que implica que as leis devam "garantir a propriedade individual" e se abster de querer igualar a propriedade, uma vez que "[...] qualquer pretensão da lei de reduzi-las à igualdade destruiria o incentivo à produtividade" (Macpherson, 1978, p. 36). Mas Bentham, denunciando seu ahistoricismo interessado, entende também que não bastaria garantir a propriedade dos frutos do próprio trabalho, mas garantir a segurança de "[...] qualquer espécie de propriedade existente, inclusive aquela que talvez não seja dos frutos do trabalho de cada um" (Macpherson, 1978, p. 37) ${ }^{27}$.

O que isso denuncia? Que por trás do projeto de transformar a ética numa geometria fica a questão de nada natural igualdade entre os homens. Menos exigentes em suas pretensões científicas, Hume e Smith, mesmo defendendo a harmonia de interesses via mercado, os direitos de propriedade, etc. não chegam a afirmar que os homens sejam igualmente proprietários e igualmente usuários das coisas que seu trabalho lhes pode prover (cujo valor ainda por cima seria avaliado conforme os graus de utilidade que tem para nós).

É evidente para qualquer leitor de A riqueza das nações que comandar trabalho alheio é uma realidade posta pela apropriação de recursos antes livres, que a divisão em classes (dos indivíduos que dispõem de riqueza acumulada e daqueles indivíduos industriosos que só dispõem da "[...] força e destreza de suas mãos [...]" (Smith, 1996a, p. 166)) é a condição da economia de mercado. Contudo, se é que as nossas tendências e esforços são dons naturais que nos colocam em pé de igualdade, Smith bem sabe que nisso há um condicionante histórico que nos torna diferentes, pois não é permitido a todos os indivíduos exercerem as mesmas condições de liberdade e segurança (Smith, 1996b). Daí o contexto no qual o autointeresse se insere como agente provedor de riqueza aparecer como relevante para Smith:

O esforço natural de cada indivíduo para melhorar a sua própria condição, quando lhe é permitido exercê-lo com liberdade e segurança, é um princípio tão poderoso que só por si e sem qualquer outro contributo é não só capaz de criar a riqueza e prosperidade de uma sociedade como ainda de vencer um grande número de obstáculos com que a insensatez das leis humanas tantas vezes cumula as suas ações (Smith, 1996b, p. 44, grifo nosso).

(27) Nessas condições Bentham afirmará: "Consultando o grande princípio de segurança, que deve o legislador decretar com respeito à massa de propriedade já existente? Ele deve manter a distribuição tal como se acha na realidade estabelecida. [...] Nada há de mais diverso que o estado da propriedade na América, na Inglaterra, na Hungria e na Rússia. De um modo geral, no primeiro desses países, o lavrador é proprietário; no segundo, arrendatário no terceiro, preso à gleba; no quarto, um escravo. Contudo, o supremo princípio da segurança exige a preservação de todas essas distribuições, embora sua natureza seja tão diferente, e embora elas não ensejem a mesma soma de felicidade" (Bentham, 1931, p. 119). 
Ao fim e ao cabo, no que se refere a este autor, seria possível ainda somar às conclusões deste trabalho uma advertência ao leitor de que muitos economistas que se debruçaram sobre Smith, ao negligenciarem a influência de Hume em seu pensamento e ao evitarem uma leitura cuidadosa de sua filosofia moral, parece, compreenderam-no segundo proposições (em especial a noção de "natureza humana") que não são fundamentalmente suas, senão que provindas de uma influência e interpretação benthaniana sobre seu legado.

\section{Referências bibliográficas}

BENTHAM, J. Escritos económicos. México: Fondo de Cultura Económica, 1965.

BENTHAM, J. Principles of the civil code. In: OGDEN, C. K. (Org.). The theory of legislation. London: [s.n.], 1931.

BENTHAM, J. Uma introdução aos princípios da moral e da legislação. São Paulo: Abril Cultural, 1974. (Os Pensadores).

BIANCHI, A. M. A pré-história da economia: de Maquiavel a Adam Smith. São Paulo: Hucitec, 1978.

CAMPBELL, T. D. Scientific explanation and ethical justification in the Moral Sentiments. In: WILSON, T.; SKINNER, A. (Ed.). The market and the state: essays in honour of Adam Smith. Oxford: Clarendon Press, 1975.

CERQUEIRA, H. G. Sobre a filosofia moral de Adam Smith. In: ENCONTRO NACIONAL DE ECONOMIA, 34., 2006. Salvador, BA. Anais eletrônicos... Salvador, BA: Anpec, 2006. Disponível em: http://www.anpec.org.br/encontro2006/artigos/A06A039.pdf. Acesso em: 27 fev. 2015.

CONTE, J. Sobre a natureza da teoria moral de Hume. Kriterion, Belo Horizonte, v. 47, n. 113, p. 131-146, jun. 2006.

DIAS, M. C. C. As diferenças entre os conceitos de moral no utilitarismo de Bentham e Stuart Mill: a moralidade como derivada das respectivas noções de natureza humana. Princípios, Natal, v. 19, n. 32, p. 483-506, jul./dez. 2012. Disponível em: http://www.principios.cchla.ufrn.br/arquivos/32P-483-506.pdf. Acesso em: 27 fev. 2015.

DIAS, M. C. C. A medida da ética em Bentham. Cadernos de Ética e Filosofia Política, São Paulo, v. 1, n. 20, p. 6-21, jun. 2013. Disponível em: http://www.revistas.usp.br/cefp/article/view/55951. Acesso em: 27 fev. 2015.

DUPUY, J. P. Introduction aux sciences sociales: logique de phénomenes collectifs. Paris: Ellipse, 1992. 
EVENSKY, J. The evolution of Adam Smith's views on political economy. History of Political Economy, v. 21, n. 1, p. 123-145, 1989.

FLEISCHACKER, S. On Adam Smith's 'Wealth of nations': a philosophical companion. Princeton: Princeton University Press, 2004.

GANEM, A. O mercado como teoria da sociedade: a radicalidade filosófica de Adam Smith. In: ENCONTRO NACIONAL DE ECONOMIA POLÍTICA, 4., 1999, Porto Alegre. Anais... Porto Alegre: UFRGS, 1999.

GANEM, A. Economia e filosofia: tensão e solução na obra de Adam Smith. Revista de Economia Política, v. 22, n. 4 (88), p. 104-118, out./dez. 2002. Disponível em: http://www.rep.org.br/pdf/88-7.pdf. Acesso em: 27 fev. 2015.

HAAKONSSEN, K. Introduction. In: SMITH, A. The theory of moral sentiments. Cambridge: Cambridge University Press, 2002.

HAAKONSSEN, K. Natural jurisprudence and the theory of justice. In: BROADIE, A. (Ed.). The Cambridge companion to the Scottish Enlightenment. Cambridge: Cambridge University Press, 2003. p. 205-221.

HUME, D. An enquiry concerning Human understanding. Oxford: Oxford University Press, 1999.

HUME, D. Resumo de um tratado da natureza humana. Porto Alegre: Paraula, 1997.

HUME, D. Ensaios morais, políticos e literários. Rio de Janeiro: Topbooks, 2004.

HUME, D. Essays moral, political and literary. Indianapolis: Liberty Fund, 1985.

HUME, D. Tratados Filosóficos II: dissertação sobre as paixões; investigação sobre os princípios da moral. Lisboa: Imprensa Nacional, Casa da Moeda, 2005. (Clássicos de Filosofia).

HUME, D. Tratado da natureza humana: uma tentativa de introduzir o método experimental de raciocínio nos assuntos morais. São Paulo: Editora Unesp, 2009.

KUHN, T. A estrutura das revoluções científicas. 3. ed. São Paulo: Perspectiva, 1989.

KIRALY, C. A. Os limites da representação: um ensaio desde a filosofia de David Hume. São Paulo: Giz Editorial, 2010a.

KIRALY, C. A. A outra modernidade de Hume. Ciência Hoje, n. 267, fev. 2010 b.

KUNTZ, R. Apresentação de Rolf Kuntz. In: PETTY, W.; HUME, D.; QUESNAY, F. Obras econômicas; escritos sobre economia: quadro econômico dos fisiocratas. São Paulo: Abril Cultural, 1983. (Os Economistas). 
LAKATOS, I.; MUSGRAVE A. A crítica e o desenvolvimento do conhecimento. São Paulo: Cultrix; Edusp, 1979.

LEVINE, A.; SOBER, E.; WRIGHT, E. O. Marxism and methodological individualism. New Left Review, n. 162, p. 67-84, Mar./Apr. 1987.

MACPHERSON, C. B. A democracia liberal: origens e evolução. Rio de Janeiro: Zahar, 1978.

MAGEE, B. Democracia e filosofia: os utilitaristas. In: HISTÓRIA da filosofia. São Paulo: Edições Loyola, 2001. p. 182-185.

MARX, K. Realidade social e pensamento. In: IANNI, O. (Org.). Marx. São Paulo: Ática, 1996. p. 177-180. (Coleção Grandes Cientistas Sociais).

MARX, K. Grundrisse: manuscritos econômicos de 1857-1858. Esboços da crítica da economia política. São Paulo: Boitempo, 2011.

MILL, J. S. Da definição de economia política e do método de investigação próprio a ela. São Paulo: Abril Cultural, 1974. (Os Pensadores).

MORROW, G. The significance of the doctrine of sympathy in Hume and Adam Smith. Philosophical Review, v. 32, n. 1, p. 60-78, Jan. 1923.

NORTON, D. F. Hume's common sense morality. In: TWEYMAN. S. (Org.). David Hume: critical assessments. London: Routledge, 1995. v. 4, p. 156-174.

PASSOS, E. S. Das Adam Smith problem: uma análise comparativa das obras A teoria do sentimentos morais e A riqueza das nações de Adam Smith. 2006. Monografia (Graduação em Ciências Econômicas)-Faculdade de Ciências Econômicas, Universidade Federal de Santa Catarina, Florianópolis, 2006. Disponível em: http://tcc.bu.ufsc.br/Economia294011. Acesso em: 27 fev. 2015.

PARETO, V. Manual de economia política. São Paulo: Nova Cultural, 1996.

PAULANI, L. Hayek e o individualismo no discurso econômico. Lua Nova, São Paulo, n. 38, p. 97-124, dez. 1996. Disponível em: http://www.scielo.br/scielo.php?pid=S0102-64451996000200006\&script=sci arttext\#tx. Acesso em: 27 fev. 2015.

PAULANI, L. Modernidade e discurso econômico. São Paulo: Boitempo, 2005. POLANYI, K.; ARENSBERG, C. M.; PEARSON, H. W. (Ed.). Trade and market in the early empires: economies in history and theory. New York: The Free Press, 1957.

POPPER, K. A lógica da pesquisa científica. São Paulo: Cultrix, 1993. 
PRADO, E. Um estudo sobre a compreensão da economia como ciência. 1989. Tese (Livre Docência)-Faculdade de Economia, Administração e Contabilidade, Universidade de São Paulo, São Paulo, 1989.

SAFATLE, V. A paixão do negativo: Lacan e a dialética. São Paulo: Unesp, 2006.

SMITH, A. A riqueza das nações. São Paulo: Nova Cultural, 1996a. v. 1 (Os Economistas).

SMITH, A. A riqueza das nações. São Paulo: Nova Cultural, 1996b. v. 2. (Os Economistas).

SMITH, A. Teoria dos sentimentos morais. São Paulo: Martins Fontes, 1999.

SEN, A. Adam Smith and the contemporary world. Erasmus Journal for Philosophy and Economics, v. 3, n. 1, p. 50-67, 2010. Disponível em: https://ejpe.org/journal/article/view/39. Acesso em: 27 fev. 2015.

VERNON, S. The two faces of Adam Smith. Southern Economic Journal, v. 65, n. 1, p. 1-19, Jul. 1998. 